\title{
Studies of para-quinomethane formation during the tyrosinase-catalyzed oxidation of 4-alkylcatechols
}

\author{
Edward J. Land, ${ }^{\text {a }}$ Christopher A. Ramsden, ${ }^{\text {a* }}$ Patrick A. Riley, ${ }^{\text {b,c }}$ \\ and Michael R. L. Stratford ${ }^{\mathrm{c}}$ \\ ${ }^{a}$ Lennard-Jones Laboratories, School of Physical and Geographical Sciences, Keele University, \\ Staffordshire ST5 5BG, United Kingdom \\ ${ }^{b}$ Totteridge Institute for Advanced Studies, The Grange, Grange Avenue, \\ London N20 8AB, United Kingdom \\ ${ }^{c}$ University of Oxford, Gray Cancer Institute, Mount Vernon Hospital, Northwood, Middlesex \\ HA6 2JR, United Kingdom \\ E-mail: c.a.ramsden@,chem.keele.ac.uk
}

\begin{abstract}
UV-Vis spectroscopy, hplc-mass spectrometry and deuterium-labeling studies demonstrate that 4-alkyl-ortho-quinones cleanly rearrange to the isomeric 2-hydroxy-para-quinomethanes over a period of 10-20 minutes in aqueous buffer. These ortho-quinones are much more stable in organic solvents $\left(\mathrm{CD}_{3} \mathrm{OH}, \mathrm{CDCl}_{3}\right)$. Studies of the rate of rearrangement and of the introduction of pre-formed para-quinomethane to enzyme solution demonstrate that the quinomethanes, formed as secondary products, do not contribute to the inactivation of tyrosinase.
\end{abstract}

Keywords: ortho-Quinones, para-quinomethanes, catechols, tyrosinase, oxidation, rearrangement

\section{Introduction}

Tyrosinase [E.C.1.14.18.1] oxidizes both phenols and catechols to ortho-quinones but the mechanisms of these transformations are different. ${ }^{1-3}$ Oxidation of phenols $\mathbf{1}$ to ortho-quinones 2 is referred to as cresolase activity and oxidation of catechols $\mathbf{3}$ to ortho-quinones $\mathbf{2}$ is referred to as catecholoxidase or catecholase activity (Scheme 1). Other enzymes can catalyse one or other of these processes but only tyrosinase catalyses both reactions. ${ }^{4}$

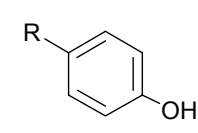

1
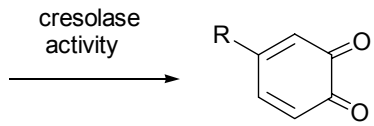

2
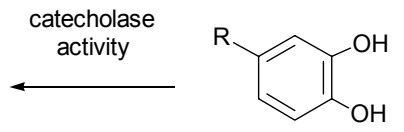

3

Scheme 1 
It has been known for many years that tyrosinase undergoes irreversible inactivation during the oxidation of catechols. ${ }^{5-16}$ No inactivation is observed during the oxidation of monohydric phenols $\mathbf{1}$. The rate at which the enzyme becomes inactive depends on the substrate structure. In 1982 Dietler and Lerch ${ }^{17}$ showed that inactivation is associated with a $50 \%$ loss of the two copper atoms in the active site of tyrosinase. We have recently carried out a substrate-structure investigation of the inactivation of mushroom tyrosinase by catechols and related inactivation by resorcinols. We have proposed that in addition to the normal catecholase oxidation that occurs via the complex 4 (Scheme 2A), a fraction of the catechol substrate presents itself as a cresolase substrate (Scheme 2B). ${ }^{18}$ The alternative enzyme substrate complex 5 can undergo deprotonation and reductive elimination leading irreversibly to $\mathrm{Cu}(0)$ and inactive tyrosinase.

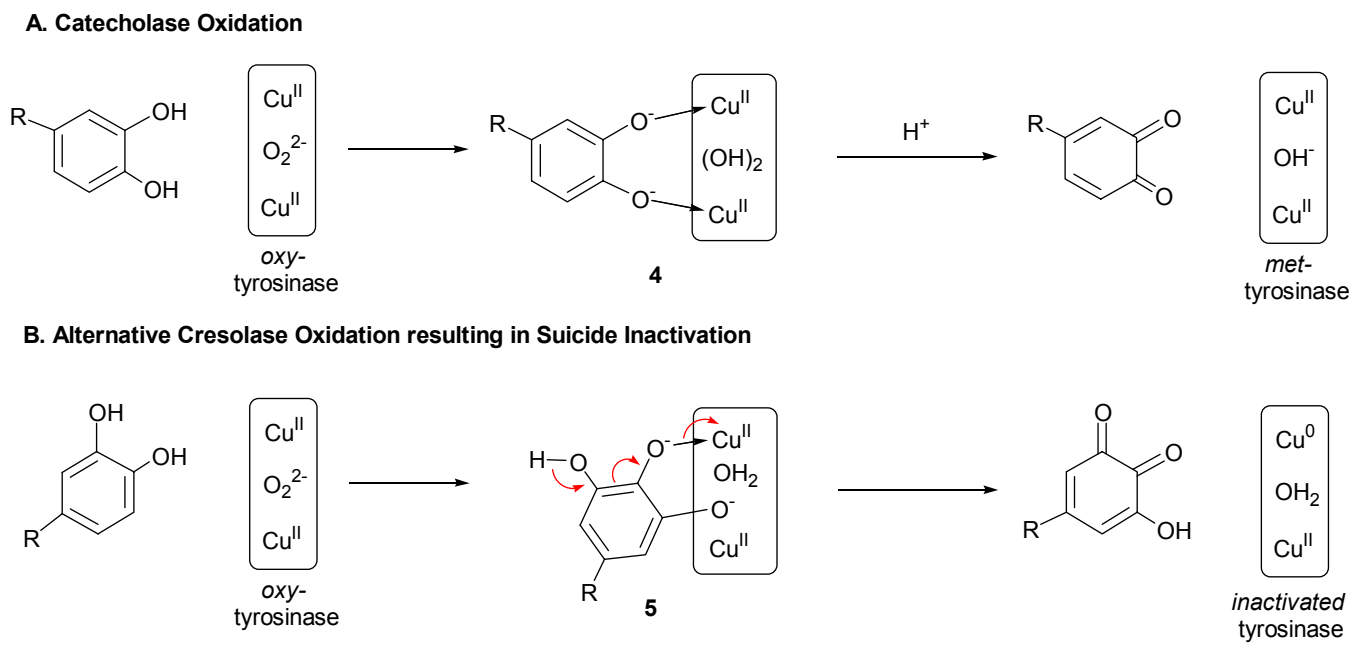

\section{Scheme 2}

In an early phase of our inactivation studies we investigated a possibility that inactivation of tyrosinase by alkylcatechols might arise from rearrangement products of the initially formed ortho-quinones $\mathbf{6}$, which we have identified as the quinomethanes 7 . This possibility was not unreasonable since several known inhibitors of tyrosinase, including kojic acid $\mathbf{8}$, mimosine $\mathbf{9}$ and tropolone 10, are associated with a copper-chelating $\alpha$-hydroxyketone fragment. ${ }^{19}$ In this paper we describe our studies of the rearrangement of 4-alkyl-ortho-quinones and show that, on the basis of kinetic and substrate-enhancement studies, the quinomethanes 7 do not contribute to tyrosinase inactivation.

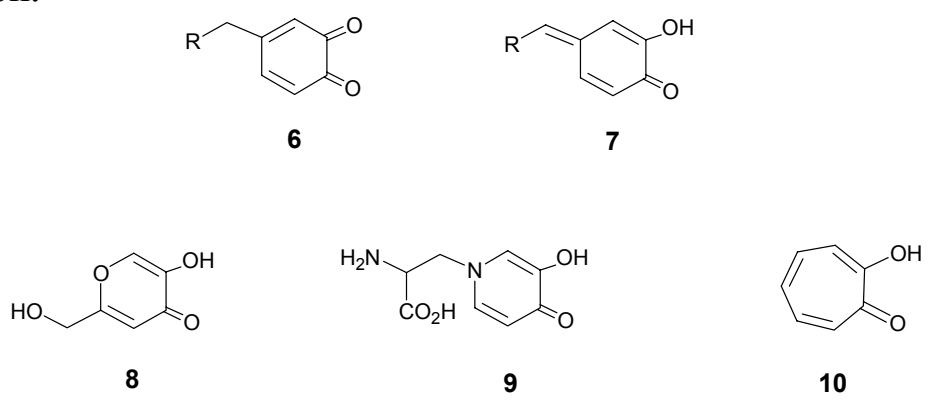




\section{Results and Discussion}

The reactivity of the ortho-quinone products of tyrosinase oxidation of catechols prompted the suggestion that the inactivation was the result of covalent binding to the enzyme and binding to tyrosinase has been demonstrated using radiolabelled substrates. ${ }^{20,21}$ However, the ortho-quinone product is also generated by oxidation of monohydric phenols and inactivation is not a feature of cresolase activity. Therefore a direct attack by the quinone product does not explain the inactivation of the enzyme.

In the early stages of our investigation of the inactivation of tyrosinase by catechols and resorcinols, we considered the possibility that the inhibitory species was a copper-chelating secondary product formed from the ortho-quinone. When comparing a series of 4-alkylcatechols for their effect on the oxygen utilization stoichiometry during tyrosinase catalyzed oxidation, we obtained spectroscopic evidence of isomerisation of the initial, rapidly formed oxidation product. The results for 4-methylcatechol are shown in Figure 1, which, after oxidation is complete, has well-defined isosbestic points at $\lambda 350$ and $456 \mathrm{~nm}$. The successive scans show decay of the initial ortho-quinone absorption $\left(\lambda_{\max } 400 \mathrm{~nm}\right)$ over a period of $c a 10$ minutes. We considered that the new product was probably the para-quinomethane $7(\mathrm{R}=\mathrm{H})$.

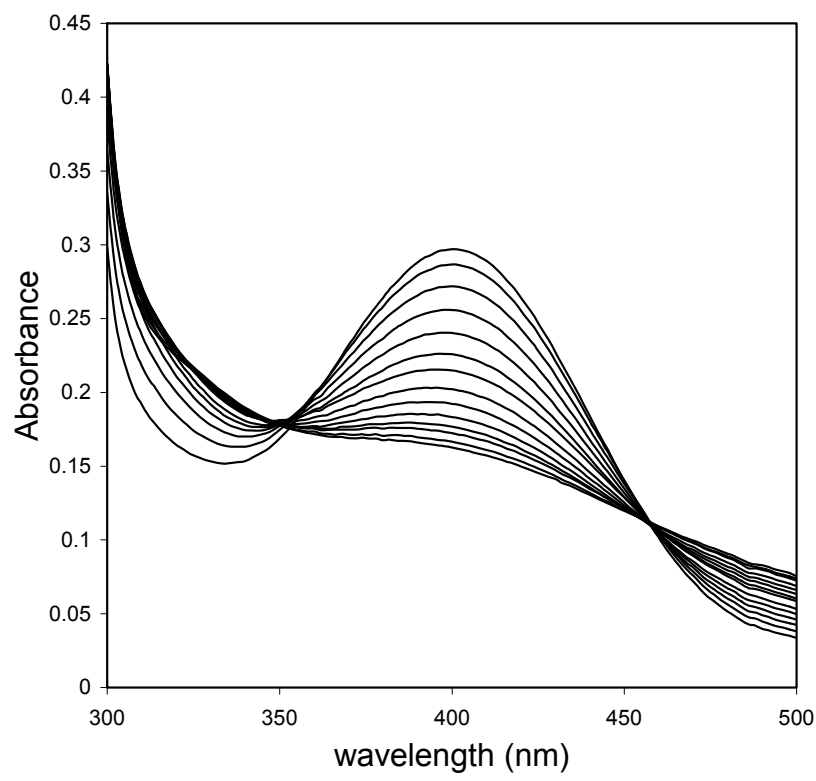

Figure 1. Successive spectral scans at $30 \mathrm{~s}$ intervals of tyrosinase-catalyzed oxidation of 4methylcatechol showing rapid formation $(60 \mathrm{~s})$ of the quinone $\left(\lambda_{\max } 400 \mathrm{~nm}\right)$ with subsequent loss of the $400 \mathrm{~nm}$ absorbing species (isosbestic points at 350 and $456 \mathrm{~nm}$ ).

Using 4-ethylcatechol, an hplc-mass spectrometry study showed the formation of an initial product, which was identified by absorbance $\left(\lambda_{\max } 401 \mathrm{~nm}\right)$ and molecular mass $\left(\mathrm{MH}^{+} \mathrm{m} / z\right.$ 137) 
as 4-ethyl-ortho-quinone 11. Over a period of $\mathrm{ca} 20$ minutes, this was converted to a second product that was more polar on hplc but exhibiting an identical mass spectrum. Figure 2 shows the chromatograms after 1 and 90 minutes. Two unidentified minor secondary products were also detected after 90 minutes. A plot of the relative amounts of quinone and product at different times during the oxidation shows the conversion kinetics (Figure 3). Assuming that the product is the quinomethane 12, in positive ion mode using electrospray ionization both molecular ions are protonated giving an identical species 13, and therefore identical spectra for reactant $\mathbf{1 1}$ and product 12 .

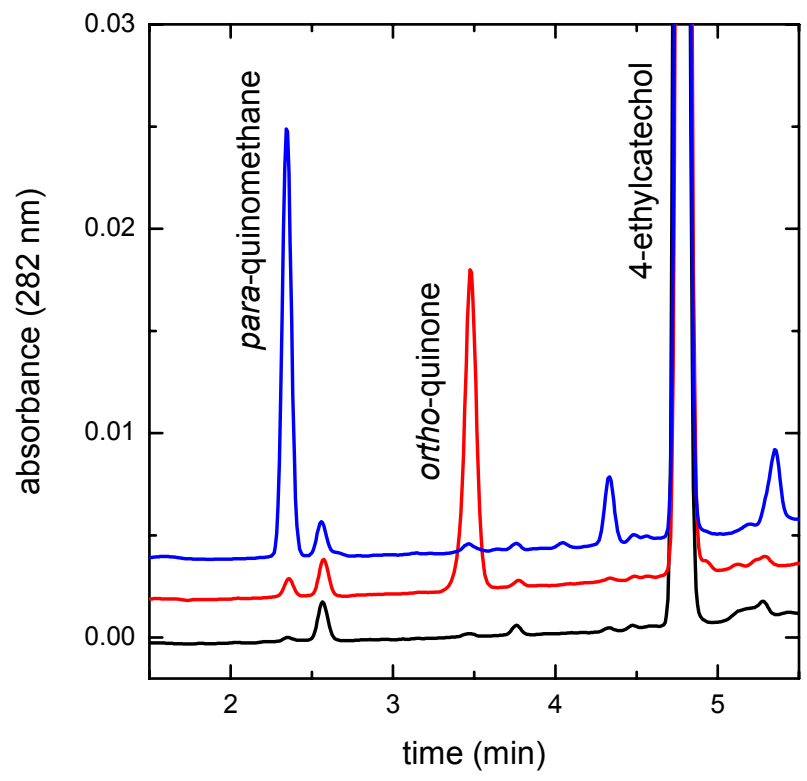

Figure 2. Hplc chromatograms of tyrosinase-catalyzed oxidation of ethylcatechol in $0.1 \mathrm{M}$ phosphate buffer: ( $\square$ ) no tyrosinase; $(\square) 1 \mathrm{~min}$; ( $\square) 90 \mathrm{~min}$.

In order to provide further unambiguous evidence that the para-quinomethane is the product, we prepared 4-(1',1'-dideuteroethyl)catechol 14. Tyrosinase oxidation of this substrate gave the dideuterated quinone $15\left(\mathrm{MH}^{+} \mathrm{m} / z 139\left(\mathrm{C}_{8} \mathrm{H}_{6} \mathrm{D}_{2} \mathrm{O}_{2}\right)\right)$ which, as expected in accord with Scheme 3, gave a monodeuterated product $\left(\mathrm{MH}^{+} \mathrm{m} / z 138\left(\mathrm{C}_{8} \mathrm{H}_{7} \mathrm{DO}_{2}\right)\right)$ entirely consistent with structure 16.

From the spectroscopic and chromatographic evidence (Figures 1 and 2) it is clear that under the conditions of tyrosinase oxidation ( $\mathrm{pH}$ 6.75) 4-ethyl-ortho-quinone is cleanly transformed to the isomeric para-quinomethane over a period of $c a 20$ minutes. Similar behaviour was observed using 4-methyl- and 4-n-propylcatechol as substrates. These results are entirely in accord with earlier studies by Bolton and co-workers who trapped para-quinomethanes as their glutathione adducts and showed that the ortho-quinone rearrangement is base catalyzed. ${ }^{22,23}$ The different 
ortho-quinone and para-quinomethane chromophores observed here are consistent with our earlier findings ${ }^{2}$ and those of the Sugumaran group. ${ }^{24,25}$

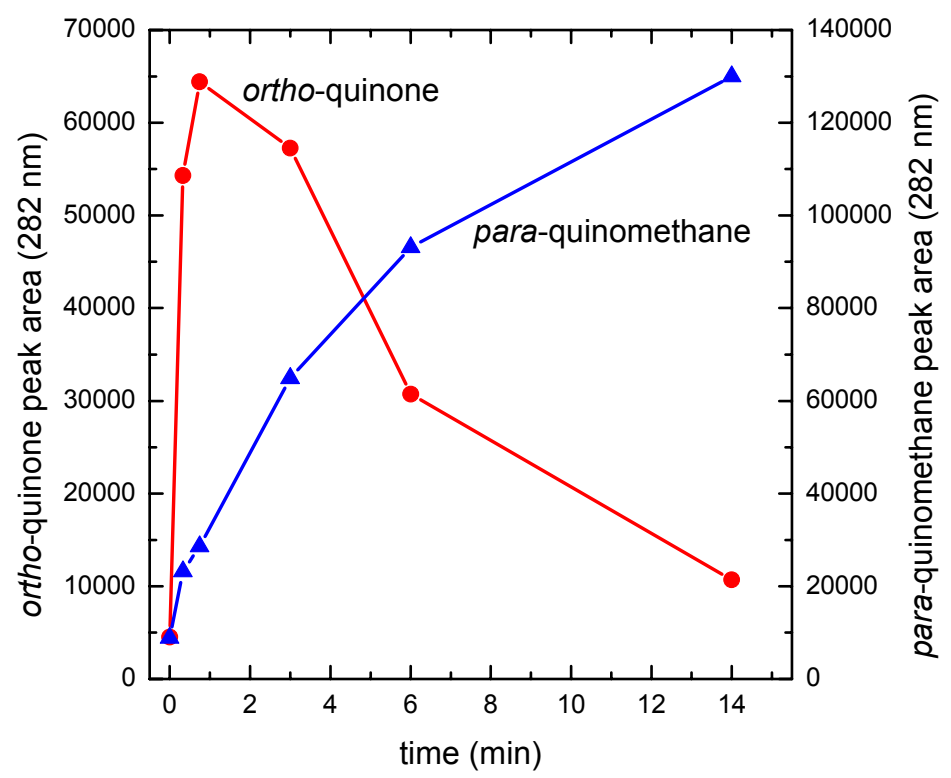

Figure 3. Kinetics of ortho-quinone formation and rearrangement to para-quinomethane during tyrosinase-catalyzed oxidation of ethylcatechol in $0.1 \mathrm{M}$ phosphate buffer.<smiles>CCC1=CC(=O)C(=O)C=C1</smiles>

11<smiles></smiles>

12

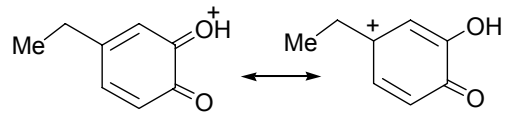

13<smiles>[2H]C([2H])(C)c1ccc(O)c(O)c1</smiles>

14<smiles>[2H]C([2H])([2H])C1=CC(=O)C(=O)C=C1</smiles>

15

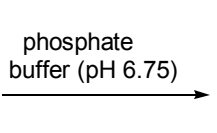<smiles>[2H]C(C)=C1C=CC(=O)C(O)=C1</smiles>

16

\section{Scheme 3}

The well-defined quinone-quinomethane rearrangement in aqueous media contrasts with the behaviour in organic solvents. We oxidized 4-ethylcatechol in (i) $\mathrm{CD}_{3} \mathrm{OH}$ and (ii) $\mathrm{CD}_{3} \mathrm{OH} /$ $\mathrm{CDCl}_{3}$ (1:9) solution using one equivalent of 2,3-dichloro-5,6-dicyano-1,4-benzoquinone (DDQ) and monitored the mixture using ${ }^{1} \mathrm{H}$ NMR. In both cases this rapidly gave a clean spectrum of 4ethyl-ortho-quinone $\left[\delta\left(\mathrm{CD}_{3} \mathrm{OH} / \mathrm{CDCl}_{3}(1: 9)\right), 5 \mathrm{~min}: 6.82(\mathrm{~d}, \mathrm{C} 6-\mathrm{H}), 6.22(\mathrm{~d}, \mathrm{C} 5-\mathrm{H}), 6.10(\mathrm{~s}\right.$, 
$\mathrm{C} 3-\mathrm{H}), 2.35\left(\mathrm{q}, \mathrm{CH}_{2}\right), 1.10\left(\mathrm{t}, \mathrm{CH}_{3}\right)$ ], which only began to show evidence of further products after several hours. After 24 hours both solutions gave complex, but different, ${ }^{1} \mathrm{H}$ NMR spectra, and due to the complexity no specific products could be identified in the mixtures. There was no evidence of clean quinomethane formation although this intermediate probably contributes to the formation of the final mixtures. It is clear that rearrangement is much faster in aqueous buffer and this can be attributed to participation of the solvent in proton transfer with base catalysis. ${ }^{23}$

We next investigated whether the significant amounts of para-quinomethane formed as secondary products during the enzymatic oxidation of 4-alkylcatechols contribute to the inactivation of tyrosinase during catechol oxidation. A solution of 4-methylcatechol $(0.4 \mathrm{mM})$ was oxidised by tyrosinase in a spectrophotometer cuvette until oxygen uptake ceased (15 min).

The reaction mixture was centrifuged using a polysulphone filter (10 kD MW cut off). The filtrate, which lacked tyrosinase activity but contained material with the absorbance profile of the para-quinomethane, was assayed by addition of 4-methylcatechol and fresh tyrosinase. The rate of oxidation of the catechol and the total oxygen utilization was the same as a control without any quinomethane present. From this result we conclude that the quinomethane shows no inhibitory activity.

We have also estimated the rate constants $\left(\mathrm{k}_{\mathrm{d}}\right)$ for the decay (i.e. rearrangement) of the orthoquinones $6(\mathrm{R}=\mathrm{Me}, \mathrm{Et}, \mathrm{nPr})$ to the corresponding para-quinomethanes 7 . In these experiments the catechol substrate $(c a 0.4 \mathrm{mM})$ was added to the enzyme solution $\left(300\right.$ units $\mathrm{mL}^{-1}$ in $0.1 \mathrm{M}$ phosphate buffer, $\mathrm{pH} 7.2$ ). Very rapid conversion to the ortho-quinone occurred and all the available oxygen was utilized in less than 2 minutes incubation. The rate of decay of the orthoquinone absorbance peak at $400 \mathrm{~nm}$ was measured. The decay constants $\left(\mathrm{k}_{\mathrm{d}}\right)$ were estimated to be as follows: $\mathrm{R}=\mathrm{Me}, \mathrm{k}_{\mathrm{d}} 0.94 \times 10^{-3} \mathrm{~s}^{-1} ; \mathrm{R}=\mathrm{Et}, \mathrm{k}_{\mathrm{d}} 0.65 \times 10^{-3} \mathrm{~s}^{-1} ; \mathrm{R}=\mathrm{nPr}, \mathrm{k}_{\mathrm{d}} 0.92 \times 10^{-3} \mathrm{~s}^{-1}$.

These rate constants are of the same order of magnitude as rate constants that we have estimated at $\mathrm{pH} 7.4$ for the amide $6\left(\mathrm{R}=\mathrm{CH}_{2} \mathrm{CH}_{2} \mathrm{NHCOMe}, \mathrm{k}_{\mathrm{d}} 4.0 \times 10^{-3} \mathrm{~s}^{-1}\right)$ and urea $6(\mathrm{R}=$ $\left.\mathrm{CH}_{2} \mathrm{CH}_{2} \mathrm{NHCONH}_{2}, \mathrm{k}_{\mathrm{d}} 0.2 \times 10^{-3} \mathrm{~s}^{-1}\right){ }^{26}$ These are all relatively slow ortho-quinone reactions and are an order of magnitude less than the enzyme inactivation rates $\left(\mathrm{R}=\mathrm{Me}, \mathrm{k}_{\mathrm{i}} 5.4 \times 10^{-2} \mathrm{~s}^{-1} ; \mathrm{R}=\right.$ Et, $\left.\mathrm{k}_{\mathrm{i}} 5.8 \times 10^{-2} \mathrm{~s}^{-1} ; \mathrm{R}=\mathrm{nPr}, \mathrm{k}_{\mathrm{i}} 1.4 \times 10^{-2} \mathrm{~s}^{-1}\right){ }^{18}$ Thus, the rates of quinomethane formation are too slow to account for the inactivation.

In a final experiment to support the conclusion that para-quinomethanes are not responsible for inactivation of tyrosinase we have shown that 4-methoxycatechol causes inactivation $\left(\mathrm{k}_{\mathrm{i}} 3.1\right.$ $\mathrm{x} 10^{-2} \mathrm{~s}^{-1}$ ) even though it cannot form a quinomethane.

\section{Conclusions}

In a series of earlier studies we have investigated the enzymatic (phosphate buffer), pulse radiolytic (phosphate buffer) and chemical (organic solvents) oxidation of a range of catechol derivatives, and we have frequently found similar results under the different conditions. ${ }^{2,27}$ Many of these studies have involved intramolecular cyclisations, which are usually very fast. Only 
when cyclisation cannot occur or is unfavourable is the much slower rearrangement to a paraquinomethane observed. It is now clear that rearrangement occurs much more readily and cleanly in aqueous media, and even under these conditions para-quinomethane formation is usually too slow to be observed using pulse radiolysis. ${ }^{28}$ We have observed rearrangement in organic solvents but these have been in cases where either the quinomethane is particularly stable ${ }^{29}$ or there is an opportunity for intramolecular proton transfer..$^{30,31}$ It is clear that if quinonequinomethane rearrangement is to be used preparatively then an aqueous solvent is highly desirable.

The studies that we have described show that under enzymatic conditions many tyrosinase substrates could form a para-quinomethane as a secondary product, including potentially undesirable metabolites. ${ }^{32}$ Our studies show that quinomethane formation does not lead to inhibition of tyrosinase even though these products 7 have similar functionality to the known inhibitors 8-10.

\section{Experimental Section}

General Procedures. Melting points were determined using a Kofler hotplate apparatus and are uncorrected. Infrared spectra were recorded on a Philips FTIR PU 9802/25 spectrophotometer with only major absorbances being quoted. ${ }^{1} \mathrm{H}$ and ${ }^{13} \mathrm{C}$ NMR (300 and $75 \mathrm{MHz}$ respectively) spectra were recorded at ambient temperatures using a Varian VXR-300 NMR spectrometer with TMS as an internal reference, and were run in deuterated chloroform solution unless otherwise stated. Chemical shifts are quoted in parts per million and the following abbreviations are used: $\mathrm{s}$ $=$ singlet $; \mathrm{d}=$ doublet; $\mathrm{t}=$ triplet; $\mathrm{q}=$ quartet; $\mathrm{sx}=$ sextet, $\mathrm{m}=$ multiplet; $\mathrm{br}=$ broad. Separations by column chromatography were carried out using silica gel S (Riedel-deHaen) $0.002-0.063 \mathrm{~mm}$ or silica gel (Janssen Chimica) $0.035-0.07 \mathrm{~mm}$. All solvents were pre-distilled and dried appropriately prior to use. Concentration and evaporation refer to the removal of volatile materials under reduced pressure on a Büchi Rotovapor.

4-Methylcatechol $3(\mathrm{R}=\mathrm{Me})$ and 4-ethylcatechol $3(\mathrm{R}=\mathrm{Et})$ were purchased from Aldrich and Johnson Matthey, respectively. 1,2-Dimethoxy-4-n-propylbenzene ${ }^{33}$ was demethylated using $48 \%$ aq $\mathrm{HBr}$ under standard conditions $\mathrm{s}^{34,35}$ to give 4-n-propylcatechol $3(\mathrm{R}=\mathrm{nPr}), \mathrm{mp} 58-59^{\circ} \mathrm{C}$ (lit. $\left.{ }^{36} \mathrm{mp} 60{ }^{\circ} \mathrm{C}\right) ; v_{\max }\left(\right.$ solid) $/ \mathrm{cm}^{-1} 3307,2958,2930,1610,1519,1445,1275,1289,1257,1193$, 1113, 786; $\delta_{\mathrm{H}}\left(\mathrm{CDCl}_{3}\right) 6.65(\mathrm{~d}, 1 \mathrm{H}, J 8 \mathrm{~Hz}$, arom H), $6.57(\mathrm{~d}, 1 \mathrm{H}, J 2 \mathrm{~Hz}$, arom H), $6.47(\mathrm{dd}, 1 \mathrm{H}$, $J 2$ and $8 \mathrm{~Hz}$, arom H), 5.48 (br.s, $2 \mathrm{H}, \mathrm{OH}), 2.32$ (t, $\left.2 \mathrm{H}, J 8 \mathrm{~Hz}, \mathrm{CH}_{2}\right), 1.43$ (sx, $2 \mathrm{H}, J 8 \mathrm{~Hz}$, $\left.\mathrm{CH}_{2}\right), 0.78\left(\mathrm{t}, 2 \mathrm{H}, J 8 \mathrm{~Hz}, \mathrm{CH}_{3}\right) ; \delta_{\mathrm{C}}\left(\mathrm{CDCl}_{3}\right) 143.6$ and $141.5(\mathrm{C}-1$ and $\mathrm{C}-2), 136.7(\mathrm{C}-4), 121.5$ (C-5), 116.2 and $115.9\left(\mathrm{C}-3\right.$ and C-6), $37.7\left(\mathrm{ArCH}_{2}\right), 25.1\left(\mathrm{CH}_{2} \mathrm{Me}\right), 14.2\left(\mathrm{CH}_{3}\right)$; $\mathrm{ms}(\mathrm{EI}) \mathrm{m} / \mathrm{z} 152$ $\left(\mathrm{M}^{+}, 90 \%\right), 123(100 \%), 105$ (15\%), 77 (35\%).

4-(1',1'-Dideuteroethyl)catechol (14). A mixture of 3',4'-dimethoxyacetophenone (1.30 g, 7.2 $\mathrm{mmol})$ and aluminium trichloride $(1.92 \mathrm{~g}, 14.4 \mathrm{mmol})$ in anhyd. $\mathrm{Et}_{2} \mathrm{O}(25 \mathrm{~mL})$ was added 
dropwise to a mixture of aluminium trichloride $(0.74 \mathrm{~g}, 5.6 \mathrm{mmol})$ and lithium aluminium deuteride $(0.23 \mathrm{~g}, 5.6 \mathrm{mmol})$ in anhyd. $\mathrm{Et}_{2} \mathrm{O}(25 \mathrm{~mL})$. The heat of reaction initiated gentle reflux and this was maintained by heating $(3 \mathrm{~h})$. Water $(25 \mathrm{~mL})$ was then added to the stirred reaction mixture followed by $6 \mathrm{~N} \mathrm{H}_{2} \mathrm{SO}_{4}(25 \mathrm{~mL})$. The $\mathrm{Et}_{2} \mathrm{O}$ layer was separated and the aqueous layer extracted with $\mathrm{Et}_{2} \mathrm{O}(25 \mathrm{~mL})$. The combined $\mathrm{Et}_{2} \mathrm{O}$ solution was washed with aq $\mathrm{NaHCO}_{3}$ and dried $\left(\mathrm{MgSO}_{4}\right)$. Evaporation gave 4-(1',1'-dideuteroethyl)-1,2-dimethoxybenzene (0.74 g, 62\%) which was purified by flash chromatography $\left(\mathrm{CHCl}_{3}\right.$ as eluent $)$ and used immediately.

A solution of 4-(1',1'-dideuteroethyl)-1,2-dimethoxybenzene (0.5 g) in $48 \%$ aq $\mathrm{HBr}(15 \mathrm{ml})$ was heated overnight at $90{ }^{\circ} \mathrm{C}$ under an $\mathrm{N}_{2}$ atmosphere. The acid was then removed by evaporation under diminished pressure. $\mathrm{MeOH}(10 \mathrm{~mL})$ was added and the solution re-evaporated to remove traces of $\mathrm{HBr}$. This process was repeated $(2 \mathrm{x})$ to give the catechol 14 as a dark oil $(0.4 \mathrm{~g}, 95 \%)$. $v_{\max }\left(\right.$ liquid film) $/ \mathrm{cm}^{-1}$ 3357, 2963, 2931, 2873, 1604, 1526, 1436, 1351, 1289, 1254, 1116, $1089,937,804,781,665 ; \delta_{\mathrm{H}}\left(\mathrm{CDCl}_{3}\right) 6.79(\mathrm{~d}, 1 \mathrm{H}, J 8 \mathrm{~Hz}$, arom. H), 6.73 (d, $1 \mathrm{H}, J 1 \mathrm{~Hz}$, arom. $\mathrm{H}), 6.63(\mathrm{dd}, 1 \mathrm{H}, J 1$ and $6 \mathrm{~Hz}$, arom. H), 5.8 (br.s, $2 \mathrm{H}, \mathrm{OH}), 1.16\left(\mathrm{~s}, 3 \mathrm{H}, \mathrm{CH}_{3}\right) ; \delta_{\mathrm{C}}\left(\mathrm{CDCl}_{3}\right)$ 143.7 and 141.5 (C-1 and C-2), 138.3 (C-4), 120.9 (C-5), 116.3 and 115.9 (C-3 and C-6), 27.9 $\left(\mathrm{CD}_{2}\right), 15.9\left(\mathrm{CH}_{3}\right)$; ms (EI) $\mathrm{m} / z 140\left(\mathrm{M}^{+}, 36 \%\right), 125$ (100\%), 79 (14\%); HRMS (EI) Found: $\left(\mathrm{M}^{+}\right) \mathrm{m} / z$ 140.0800, Calc. for $\mathrm{C}_{8} \mathrm{H}_{8} \mathrm{D}_{2} \mathrm{O}_{2}: m / z 140.0801$.

Enzyme studies. A stock solution of the substrate was made up in distilled water and added to $0.1 \mathrm{M}$ phosphate buffer ( $\mathrm{pH}$ 6.75). Oxidation was initiated by the addition of tyrosinase (ex Agaricus bisporus) and the reaction mixture incubated at $21{ }^{\circ} \mathrm{C}$ in a stoppered cuvette of $3.65 \mathrm{~mL}$ volume. The progress of the reaction was monitored by oximetry (Clark electrode) and spectrophotometry as previously described. ${ }^{37}$ For hplc/mass spectrum studies $100 \mu \mathrm{L}$ samples were withdrawn and the enzyme precipitated by the addition of trichloroacetic acid (TCA) (10\% final concentration). After centrifuging of the sample, the supernatant liquid was injected onto the hplc column. The chromatograms in Figure 2 were generated by incubating the substrate with tyrosinase in the hplc autosampler vial and injecting directly into the hplc without addition of TCA. To separate the quinomethane the final reaction mixture was centrifuged for 15 mins at $5000 \mathrm{x} \mathrm{g}$ in a tube containing a polysulphone filter with MW cut off of $10 \mathrm{kD}$ (Watman VectaSpin 3) and the filtrate collected and re-introduced into the test cuvette. Addition of fresh substrate failed to initiate oxygen uptake, demonstrating the absence of enzyme. On enzyme addition the reaction proceeded as normal and the rate and extent of oxygen uptake was the same as the appropriate controls. Rearrangement rates were determined using an enzyme concentration of 300 units $\mathrm{mL}^{-1}$ to ensure that the added substrate was rapidly oxidized and that all the available oxygen was utilized, thus preventing interference from residual oxidation. The rate of decay was estimated from the loss of absorbance at $400 \mathrm{~nm}$.

Hplc studies. Separations were carried out using a Waters 2695 separations module (Waters, Elstree, UK) with a Hichrom RPB, 100 x $3.2 \mathrm{~mm}$ hplc column (Hichrom, Reading, UK) maintained at $35{ }^{\circ} \mathrm{C}$. The hplc eluents were: A, $0.1 \%$ formic acid; B, methanol, with a gradient of 
$10-70 \% \mathrm{~B}$ over $5 \mathrm{~min}$. The flow rate was $1.0 \mathrm{~mL} \mathrm{~min}^{-1}$, which was split after diode array detection to give a flow rate of $\sim 200 \mu \mathrm{L} \mathrm{min}{ }^{-1}$ to the mass spectrometer. The eluent was monitored using a Waters 2996 diode array detector $(215-450 \mathrm{~nm}, 2.4 \mathrm{~nm}$ resolution) and a Waters Micromass ZQ mass detector (mass range 110-300 Da) in positive ion mode using electrospray ionization, and using Waters Empower 2 software. The mass detector employed the following conditions: capillary voltage, $2.5 \mathrm{kV}$; cone voltage, $20 \mathrm{~V}$; source temperature, $120{ }^{\circ} \mathrm{C}$; desolvation temperature, $425^{\circ} \mathrm{C}$; desolvation gas flow, $450 \mathrm{~L} \mathrm{~h}^{-1}$; cone gas flow, $100 \mathrm{~L} \mathrm{~h}^{-1}$.

\section{Acknowledgements}

We thank the EPSRC National Mass Spectrometry Service Centre, Swansea for high-resolution mass spectra and Unilever R \& D for financial support. We also thank John Clews (Keele) for the preparation of catechols and Professor Peter Wardman (Gray Cancer Institute) for provision of laboratory facilities.

\section{References}

1. Decker, H.; Dillinger, R.; Tuczek, F. Angew. Chem. Int. Ed. 2000, 39, 1591.

2. Land, E. J.; Ramsden, C. A.; Riley, P. A. Acc. Chem. Res. 2003, 36, 300.

3. Decker, H.; Schweikardt, T.; Tuczek, F. Angew. Chem. Int. Ed. 2006, 45, 4546.

4. Mason, H. S. Adv. Enz., 1955, 16, 105.

5. Nelson, J. M.; Dawson, C. R. Adv. Enz. 1944, 4, 99.

6. Asimov, I.; Dawson, C. R. J. Biol. Chem. 1950, 72, 820.

7. Ingraham, L. L.; Corse, J.; Makower, B. J. Am. Chem. Soc. 1952, 74, 2623.

8. Tomita, Y.; Seiji, M. J. Dermatol. 1977, 4, 245.

9. Tomita, Y.; Hariu, A.; Mizuno, C.; Seiji, M. J. Invest. Dermatol. 1980, 75, 379.

10. Lerch, K. Mol. Cell. Biochem. 1983, 52, 125.

11. Miranda, M.; Botti, D. Gen. Pharmacol. 1983, 14, 231.

12. Waley, S. G. Biochem. J. 1985, 227, 843.

13. Garcia-Canovas, F.; Tudela, J.; Martinez-Madrid, C.; Varon, R.; Garcia-Carmona, F.; Lozano, J. A. Biochim. Biophys. Acta 1987, 912, 417.

14. Tudela, J.; Garcia-Canovas, F.; Varon, R.; Jimenez, M.; Garcia-Carmona F.; Lozano J. A. Biophys. Chem. 1988, 30, 303.

15. Haghbeen, K.; Saboury, A. A.; Karbassi, F. Biochim. Biophys. Acta 2004, 1675, 139.

16. Garcia-Molina, F.; Hiner, A. N. P.; Fenoll, L. G.; Rodriguez-Lopez, J. N.; Garcia-Ruiz, P. A.; Garcia-Canovas, F.; Tudela J. J. Agric. Food Chem. 2005, 53, 3702.

17. Dietler, C.; Lerch, K. In: Oxidases and Related Redox Systems, (King, T. E.; Mason, H. S.; Morrison, M., eds). New York: (1982) Pergamon Press; pp. 305-307. 
18. Land, E. J.; Ramsden, C. A.; Riley, P. A. Tohoku J. Exp. Med. 2007, 212, 341.

19. Prota, G. Melanins and Melanogenesis, Academic Press, Inc, San Diego, 1992.

20. Wood, B. J. B.; Ingraham, L. L. Nature 1965, 205, 291.

21. Naish-Byfield, S.; Riley, P. A. Pigment Cell Res. 1998, 11, 127.

22. Iverson, S. L.; Hu, L. Q.; Vukomanovic, V.; Bolton, J. L. Chem. Res. Toxicol. 1995, 8, 537.

23. Bolton, J. L.; Wu, H. M.; Hu, L. Q. Chem. Res. Toxicol. 1996, 9, 109.

24. Sugumaran, M. Pigment Cell. Res. 2002, 15, 2.

25. Sugumaran, M.; Semensi, V.; Kalyanaraman, B.; Bruce, J. M.; Land, E. J. J. Biol. Chem. 1992, 267, 10355.

26. Borovansky, J.; Edge, R.; Land, E. J.; Navaratnam, S.; Pavel, S.; Ramsden, C. A.; Riley, P. A.; Smit, N. P. M. Pigment Cell Res. 2006, 19, 170.

27. Land, E. J.; Ramsden, C. A.; Riley, P. A. ARKIVOC 2007, (xi), 23.

28. Land, E. J.; Ramsden, C. A.; Riley, P. A.; Yoganathan, G. Pigment Cell Res. 2003, 16, 397.

29. Land, E. J.; Ramsden, C. A.; Riley, P. A.; Yoganathan, G. Tetrahedron 2003, 59, 9547.

30. Clews, J.; Cooksey, C. J.; Garratt, P. J.; Land, E. J.; Ramsden, C. A.; Riley, P.A. J. Chem. Soc., Perkin Trans 1 2000, 4306.

31. Land, E. J.; Ramsden, C. A.; Riley, P. A.; Yoganathan, G. Org. Biomol. Chem. 2003, 1, 3120.

32. Pezzella, A.; Lista, L.; Napolitano, A.; d'Ischia, M. Chem. Res. Toxicol. 2005, 18, 1413.

33. Hewgill, F. R.; Pass, M. C. Aust. J. Chem. 1985, 38, 555.

34. Ginos, J. Z.; Cotzias, G. C.; Tolosa, E.; Tang L. C.; Lomonte, A. J. Med. Chem. 1975, 18, 1194.

35. Cannon, J. G.; Hsu, F-L.; Long, J. P.; Flynn, J. R.; Costall B.; Naylor, R. J. J. Med. Chem. 1978, 21, 248.

36. Späth, E.; Quietensky, H. Chem. Ber. 1927, 60, 1888.

37. Cooksey, C. J.; Garratt, P. J.; Land, E. J.; Pavel, S.; Ramsden C. A.; Riley, P. A.; Smit, N. P. M. J. Biol. Chem. 1997, 272, 26226. 